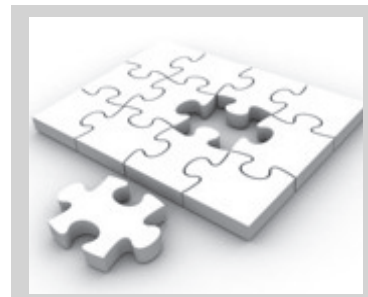

In an effort to facilitate the selection of appropriate peer reviewers for HTS Teologiese Studies/ Theological Studies, we ask that you take a moment to update your electronic portfolio on www.hts. org.za for our files, allowing us better access to your areas of interest and expertise, in order to match reviewers with submitted manuscripts.

If you would like to become a reviewer, please visit the journal website and register as a reviewer.

To access your details on the website, you will need to follow these steps:

1. Log into the online journal at http://www.hts. org.za

2. In your 'user home' [http://www.hts.org.za/ index.php/hts/user] select 'edit my profile' under the heading 'my account' and insert all relevant details, bio statement and reviewing interest.

It is good practice as a reviewer to update your personal details regularly to ensure contact with you throughout your professional term as a reviewer to HTS Teologiese Studies/Theological Studies.

Please do not hesitate to contact us if you require assistance in performing this task.

Publisher: publishing@aosis.co.za Tel: +27 219752602

Fax: +27 219754635

\section{HTS $\mathrm{H}$ S THEOLOGICAL STUDIES}

HTS Teologiese Studies/Theological Studies recognises the value and importance of the peer reviewer in the overall publication process - not only in shaping the individual manuscript, but also in shaping the credibility and reputation of our journal.

We are committed to the timely publication of all original, innovative contributions submitted for publication. As such, the identification and selection of reviewers who have expertise and interest in the topics appropriate to each manuscript are essential elements in ensuring a timely, productive peer review process.

We would like to take this opportunity to thank all reviewers who participated in shaping this volume of HTS Teologiese Studies/Theological Studies:
Abraham (Bram) van de Beek

Ananda Geyser-Fouche

Andries G. van Aarde

Anita L. Cloete

Anné H. Verhoef

Anneke Viljoen

Annelie Botha

Annemie Dillen

Barry J. van Wyk

Carel (Callie) F.C. Coetzee

Chris le Roux

Christoffel Lombaard

Christopher Hays

Coenie Calitz

Elritia le Roux

Erna Oliver

Ernest van Eck

Frans J. Boshoff

George O. Folarin

Gerda de Villiers

Gert J. Malan

Hans van Deventer

Hendrik Goede
Hennie Viviers
Herculaas (Herrie) F. van Rooy
Ignatius Swart
Ignatius W.C. (Natie) van Wyk
In-Cheol Shin
J. (Kobus) P. Labuschagne
J. Christo van der Merwe
Jaco Beyers
Jacob Meiring
Jacobus W. Gericke
Jakub Urbaniak
Jan G. van der Watt
Jean-Claude Loba Mkole
Johann-Albrecht Meylahn
John de Gruchy
Joseph Ogbonnaya
Juanita Meyer
Llewellyn Howes
Lyzette Hoffman
Marius J. Nel
Paul P. Kruger

Peter Nagel

Peter White

Petrus L. Steenkamp

Philippus (Phil) J. Botha

Philippus R. (Flip) du Toit

Piet B. Boshoof

Pieter M. Venter

Robert Dykstra

Robert J. Jones

Ronald H. van der Bergh

Rudy A. Denton

Selaelo T. Kgatla

Shaun Joynt

Stephan de Beer

Thinus van Staden

Wessel Bentley

Wouter C. van Wyk

Yolanda Dreyer

Yolande Steenkamp

Zorodzai Dube
Rosemaré A. Visser

We appreciate the time taken to perform your review successfully. Should names have inadvertently been excluded from this list the publisher apologises and undertakes to amend the exclusion in the next volume. 